\title{
1 Modeling Regional Effects of Climate Change on Soil Organic Carbon in
}

\section{Spain}

3 Asma Jebari,* Agustin del Prado, Guillermo Pardo, José Antonio Rodríguez Martín, and

4 Jorge Álvaro-Fuentes

5 A. Jebari, A. del Prado, and G. Pardo, Basque Centre for Climate Change (BC3), Edificio Sede no. 1, Planta

6 1, Parque Científico de UPV/EHU, Barrio Sarriena s/n, 48940 Leioa, Bizkaia, Spain; J.A. Rodríguez Martín,

7 Dep. Environment, Instituto Nacional de Investigación y Tecnología Agraria y Alimentaria (INIA), Carretera

8 La Coruña 7.5, 28040, Madrid, Spain; J.J. Álvaro-Fuentes, Soil and Water Dep., Estación Experimental de

9 Aula Dei (EEAD), Spanish National Research Council (CSIC), Av. Montañana, 1005, 50059 Zaragoza,

10 Spain. Assigned to Associate Editor Hero Gollany.

12 *Corresponding author (asmajebari543@yahoo.com).

13 Abbreviations: DPM, decomposable plant material; HI, harvest index; NT, no-tillage; RPM, resistant plant

14 material; SOC, soil organic carbon; SOM, soil organic matter.

15 Core Ideas

16 The model predicted a general increase in SOC stocks by 2100 in all climate scenarios

17 Irrigated crops showed the largest SOC stocks

18 Carbon inputs were the most important driver for SOC stocks

19 No-tillage and cover crops have at least doubled SOC sequestration rates 


\section{ABSTRACT}

22 Soil organic C (SOC) stock assessments at the regional scale under climate change

23 scenarios are of paramount importance in implementing soil management practices to

24 mitigate climate change. In this study, we estimated the changes in SOC sequestration

25 under climate change conditions in agricultural land in Spain using the RothC model at the

26 regional level. Four Intergovernmental Panel on Climate Change (IPCC) climate change

27 scenarios (CGCM2-A2, CGCM2-B2, ECHAM4-A2, and ECHAM4-B2) were used to

28 simulate SOC changes during the 2010 to 2100 period across a total surface area of 2.33 .

$2910^{4} \mathrm{~km}^{2}$. Although RothC predicted a general increase in SOC stocks by 2100 under all

30 climate change scenarios, these SOC sequestration rates were smaller than those under

31 baseline conditions. Moreover, this SOC response differed among climate change

32 scenarios, and in some situations, some losses of SOC occurred. The greatest losses of C

33 stocks were found mainly in the ECHAM4 (highest temperature rise and precipitation

34 drop) scenarios and for rainfed and certain woody crops (lower C inputs). Under climate

35 change conditions, management practices including no-tillage for rainfed crops and

36 vegetation cover for woody crops were predicted to double and quadruple $\mathrm{C}$ sequestration

37 rates, reaching values of 0.47 and $0.35 \mathrm{MgC} \mathrm{ha}^{-1} \mathrm{yr}^{-1}$, respectively. 


\section{INTRODUCTION}

40 Agricultural activities significantly contribute to global emissions of the major greenhouse

41 gases $\left(\mathrm{CO}_{2}, \mathrm{CH}_{4}\right.$, and $\left.\mathrm{N}_{2} \mathrm{O}\right)$ (Paustian et al., 2004). Nevertheless, in the agricultural sector,

42 there are several options to mitigate climate change effects by either reducing the sources

43 of greenhouse gas emissions, enhancing their sinks (e.g., negative emissions via $\mathrm{CO}_{2}$

44 sequestration), or reducing $\mathrm{CO}_{2}$ emissions by substitution of biological products for fossil

45 fuels or energy-intensive products (Smith et al., 2014). In the recent decades, special

46 attention has been paid to soil organic C (SOC) sequestration and its role in mitigating

47 climate change. Although estimates are subject to a large degree of uncertainty, optimistic

48 studies (e.g., Hansen et al., 2013) suggest that global agricultural soils could sequester at

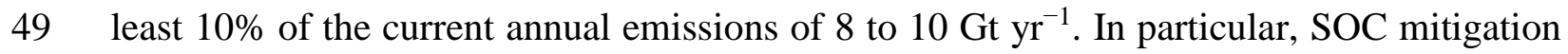

50 potential for European croplands is estimated between 9 and $38 \mathrm{Mt} \mathrm{CO}_{2} \mathrm{yr}^{-1}$ by 2050

51 (Frank et al., 2015). Furthermore, increasing SOC is vital to the ecosystem functioning as a

52 consequence of the positive effects on soil structure, water retention, and cation exchange

53 capacity (van Keulen, 2001), thus contributing to enhanced soil quality and water

54 availability (Johnston et al., 2009). Agricultural intensification has caused growth in the

55 use of management practices that lead to decreasing SOC stocks (e.g., monoculturing,

56 overtillage). The application of improved agricultural management practices that lead to

57 both enhanced SOC sequestration and increased soil fertility is therefore required for 
58 climate change mitigation (Haddaway et al., 2015). Among these potential mitigating

59 practices, conservation tillage (minimum tillage and no-tillage [NT]) has been

60 recommended for semiarid areas of the Mediterranean basin (López-Garrido et al., 2014),

61 since it (i) increases SOC stocks through developing macroaggregates (Panettieri et al.,

62 2015), (ii) prevents soil disturbance and SOC decomposition (Peterson et al., 1998; Plaza-

63 Bonilla et al., 2010), (iii) enhances water use efficiency (Lampurlanés et al., 2016), and

64 consequently, (iv) may lead to higher yields than conventional tillage systems (De Vita et

65 al., 2007; Morell et al., 2011). The application of organic amendments to agricultural soils

66 and the use of cover crops are also regarded as effective ways of restoring soil C stocks.

67 Experimental and modeling studies have successfully shown an increase in SOC after

68 application of organic amendments such as pruning residues (Sofo et al., 2005) or compost

69 (Mondini et al., 2012), and using cover crops for both woody (Pardo et al., 2017) and

70 arable (Bleuler et al., 2017) cropping systems.

71 Supplying stakeholders and policymakers with scientifically robust information on soil

72 management practices to restore and increase $\mathrm{C}$ stocks is paramount in developing

73 appropriate strategies to mitigate climate change. In this sense, SOC models provide

74 reliable and practical information, as they can estimate SOC potential and assess future

75 trends (Mondini et al., 2012). Using dynamic SOC models at a regional scale, thus linking

76 GIS with soil organic matter (SOM) models (Farina et al., 2017), enables us not only to 
77 consider the local parameters that control SOM dynamics (e.g., soil properties, climate, and

78 land use), but also to analyze their spatial variability. In this context, the SOM model

79 RothC (Coleman and Jenkinson, 1996) has been applied to numerous field studies

80 worldwide under various types of agricultural management and agroclimatic regions

81 (Jenkinson et al., 1999; Kaonga and Coleman., 2008; Liu et al., 2009). In Mediterranean

82 Spain, process-based models (e.g., the Century model: Álvaro-Fuentes et al., 2012a) have

83 already been used at the plot (Nieto et al., 2010; Álvaro-Fuentes et al., 2012b; Nieto and

84 Castro, 2013) and regional (Álvaro-Fuentes et al., 2012a; Pardo et al., 2017) scales. Among

85 these studies, Álvaro-Fuentes et al. (2012a) was been the first to investigate the effect of

86 Spanish climate change conditions on SOC changes at the regional level, but they did not

87 use the $\mathrm{C}$ model under a spatially explicit environment. Therefore, to our knowledge, there

88 have not been many studies so far investigating SOC dynamics at the regional scale,

89 linking GIS with SOC models and considering climate change conditions. Accordingly, the

90 main general aim of this study was to evaluate the impact of climate change on SOC

91 content at a regional level in Spain using the RothC simulation model. In this context and

92 to make the assessment more relevant for decision making, we included spatial mapping

93 and recommended soil management practices. Furthermore, different alternative

94 management practices to increase SOC sequestration under climate change conditions were

95 also simulated. We hypothesized that (i) climate change conditions would reduce SOC 
96 sequestration capacity, and (ii) alternative management practices could help to enhance soil

97 C sequestration under climate change conditions.

\section{MATERIALS AND METHODS}

\section{Study Area}

100 Our study area $\left(47,719 \mathrm{~km}^{2}\right)$ in northeastern Spain comprised the entire Aragon

101 autonomous community. This is located at the center of the Ebro River depression, an

102 enclosed basin situated between two high mountain ranges: the Pyrenees in the north and

103 the Iberian mountains in the south. This location has an irregular orography and large

104 climate heterogeneity. Annual precipitation in the central part of the region rarely reaches

$105400 \mathrm{~mm}$, with mean air temperatures close to $14^{\circ} \mathrm{C}$. In contrast, in the northern and

106 southern areas (the Pyrenees and the Iberian mountains, respectively), annual precipitation

107 reaches 1000 mm (Cuadrat, 1999; Peña et al., 2002).

108 In the Aragon region, agricultural land occupies 49\% of the total surface. Field crops

109 occupy almost $80 \%$ of the agricultural area, involving rainfed (74\%) and irrigated (36\%)

110 land. The main crops in the rainfed areas are barley (Hordeum vulgare L., 65\%) and wheat

111 (Triticum aestivum L., 31\%). As for irrigated crops, corn (Zea mays L., 47\%) and barley

$112(22 \%)$ are the most abundant crops, with smaller proportions of wheat and alfalfa

113 (Medicago sativa L.). Woody crops in Aragon represent 30\% of the sales of vegetative 
114 products of the study area, with almonds (Prunus dulcis L.), olives (Olea europaea L.), and

115 grapes (Vitis vinifera L.) as the main crops (DGA, 2012).

116 Rain-fed crops are commonly managed under either cereal-fallow rotations or

117 monocropping together with intensive tillage (56\% of rainfed surface is intensively tilled).

118 However, land managed under conservation tillage (i.e., NT) instead of intensive tillage

119 has increased in recent years, representing 20\% of land surface currently (DGA, 2012).

120 Within irrigated crops, corn (47\%), barley (22\%), and wheat (17\%) are commonly grown

121 as part of a rotation (GEA, 2000). Surface irrigation and sprinkler irrigation systems are

122 most widely used at similar rates (MAPAMA, 2013). Regarding tree crops, the most

123 generalized practice is minimum soil tillage, representing 55\% of woody crop surfaces

124 (DGA, 2012).

\section{The RothC Model}

126 The RothC model (Coleman and Jenkinson, 1996) requires a small number of easily

127 available input data and has been widely used to simulate the impact of agricultural land

128 management on SOC changes (Coleman et al., 1997; Falloon and Smith, 2002; Johnston et

129 al., 2009). As a summary, the RothC model divides the SOC into five fractions: four of

130 them are active, and one is inert (i.e., inert organic matter). The active pools are

131 decomposable plant material (DPM), resistant plant material (RPM), microbial biomass, 
132 and humified organic matter. The decomposition of each pool (except inert organic matter)

133 is governed by first-order kinetics $\left(\mathrm{yr}^{-1}\right)$, characterized by its own turnover rate constant

134 (10 for DPM, 0.3 for RPM, 0.66 for microbial biomass, and 0.02 for humified organic

135 matter) and modified by factors related to air temperature, soil moisture, and vegetation

136 cover, which are main input parameters to run the model. RothC does not include a plant

137 growth module, and thus plant $\mathrm{C}$ inputs to soil have to be entered as exogenous inputs to

138 the model. Incoming plant $C$ is split between DPM and RPM, depending on the DPM/RPM

139 ratio of the particular incoming plant material or organic residue. Both of them decompose

140 to produce microbial biomass, humified organic matter, and evolved $\mathrm{CO}_{2}$. For most

141 agricultural crops and improved grasslands, a DPM/RPM ratio of 1.44 is used (i.e., 59\% of

142 the plant material is DPM and $41 \%$ is RPM; Jones et al., 2005).

143 The model uses a monthly time step to calculate total SOC and its different pools on a

144 years-to-centuries timescale. The climate input parameters include monthly average air

145 temperature, monthly precipitation, and monthly open-pan evaporation. Other input

146 parameters are soil clay content, monthly $\mathrm{C}$ input from plant residues or exogenous organic

147 matter (e.g., manure), and monthly information on soil cover, whether the soil is bare or

148 covered by plants. 


\section{Input Datasets and Spatial Layer Linkages}

150 The Aragon autonomous community covers 21 agricultural regions. Information on

151 agricultural land uses was obtained from the Corine Land Cover. We distinguished five

152 main classes of land cover: rainfed arable land, irrigated arable land, orchards, olive

153 groves, and vineyards. The last three classes were compressed into a general class of

154 woody crops. Soil data were obtained from a recent assessment at the national level (López

155 Arias and Grau Corbí, 2005). In this assessment, among others, variables such as soil

156 texture and SOC to the 30-cm soil depth were analyzed and spatially represented for the

157 entire Spanish area (Rodríguez Martín et al., 2009). For our study, a total of 309

158 georeferenced points were selected (Supplemental Fig. S1). We set up an equal-interval

159 classification (five intervals) and a mean value of each interval for SOC stocks and clay

160 content properties layers (Supplemental Fig. S2) to overcome the large variability in both

161 SOC stocks (25-151 $\left.\mathrm{Mg} \mathrm{ha}^{-1}\right)$ and clay content (14-30\%) across the area studied.

162 Climate change data, corresponding to $50-\mathrm{km} \square 60-\mathrm{km}$ grids, were produced by the

163 Meteorological State Agency using a regionalization technique explained in Brunet et al.

164 (2008). We simulated SOC changes for the period of 2010 to 2100 under four climate

165 change scenarios and one baseline scenario. The latter consisted of historical average

166 monthly temperature and precipitation data of more than one decade. The four climate 
167 change scenarios were obtained from two atmosphere-ocean global circulation models,

168 ECHAM4 and CGCM2, forced by two Intergovernmental Panel on Climate Change

169 (IPCC) Special Report on Emissions Scenarios, A2 (medium-high emissions scenario) and

170 B2 (medium-low emissions scenario) (Nakicenovic et al., 2000; more details can be found

171 in the section "Climate Change Scenarios" below). Furthermore, potential

172 evapotranspiration for each decade from 2010 to 2100 was estimated monthly using air

173 temperature according to the Hargreaves method (Allen et al., 1998).

174 The overlay of climate grids on the spatial layers of agricultural land uses and clay

175 content through ArcMap 10. 2. 2 (MaDGIC, 2014) resulted in 1337 individual polygons.

176 Mean SOC stocks for initialization purposes were assigned to the spatial units through a

177 query operated in Microsoft Access.

178 Model Running and Parametrization

179 Carbon inputs derived from plants and animal manure application were estimated. To

180 explore the maximum potential for SOC sequestration in the study area, simulations were

181 performed assuming that all plant residues were returned to the soil. Within rainfed and

182 irrigated crops, annual average crop yield values for the 2003 to 2013 period were obtained

183 from the Agricultural Statistical Yearbook of Aragon (DGA, 2012). Total aboveground

184 biomass was estimated from crop yields using average harvest index (HI) values obtained 
185 from different studies performed in the study area (Daudén and Quilez, 2004; Daudén et

186 al., 2004; Moret et al., 2007; Berenguer et al., 2009; Yagüe and Quilez, 2010a, 2010b;

187 Álvaro-Fuentes et al., 2013; Erice et al., 2014; Plaza-Bonilla et al., 2014). After an

188 extensive literature review of the study conditions, HI values were set to 0.42 and 0.38 for

189 rainfed and irrigated crops, respectively. We assigned a $\mathrm{HI}$ of 0.50 to corn, assuming its

190 different morphology compared with the other irrigated crops. Belowground plant residues

191 were estimated from shoot/root ratio. Similarly to HI, a literature review was performed to

192 obtain mean shoot/root values representative of the study area (Lohaus et al., 1998;

193 Vamerali et al., 2003; Plaza-Bonilla et al., 2014). The final mean shoot/root values were

194 fixed to 4.12, 7.66, and 2.21 for rainfed crops, irrigated crops, and corn, respectively. For

195 both irrigated and rainfed crops, we assumed that $50 \%$ of $\mathrm{C}$ inputs occurred in the month of

196 harvest and the remaining $50 \%$ in the three previous months.

197 For woody crops, pruning residues were also estimated using data obtained from

198 studies performed in Spain or in similar Mediterranean conditions (Di Blasi et al., 1997;

199 González et al., 2005; Nieto et al., 2010; Velazquez-Marti et al., 2011; Aguilera et al.,

200 2015). The final pruning values considered were $1.52,2.90$, and $4.80 \mathrm{Mg} \mathrm{ha}^{-1}$ for olive

201 groves, vineyards, and orchards, respectively. We assumed that $70 \%$ of the $\mathrm{C}$ inputs

202 occurred in the pruning months and the remaining 30\% during the four previous months.

203 Carbon inputs from animal manure application were based on the studies of Sanz-Cobeña 
204 et al. (2014) and Pardo el al. (2017) and were calculated as follows: dry matter excretion

205 rates $\left(\mathrm{kg} \mathrm{location}^{-1} \mathrm{yr}^{-1}\right)$ for livestock were first obtained from the National Inventory

206 Report (MAPAMA, 2011) and then subsequently multiplied by the livestock population of

207 each animal category for 2008 and for each agricultural region (MAPAMA, 2009).

208 Outdoor grazing animals' excreta were assumed to reach mainly grasslands, which were

209 not included in the present study. Consequently, to estimate manure flows applied to

210 croplands, we deducted animal excretion during grazing from the total excreta by applying

211 the grazing factor proposed by the Spanish National Inventory (UNFCCC, 2014). Finally,

212 manure flows applied to cropland dry matter was converted to $\mathrm{C}$ by assuming $80 \%$ content

213 of volatile solids and $55 \%$ of $\mathrm{C}$ content in volatile solids. (Adams et al., 1951). We

214 assumed that $\mathrm{C}$ inputs of animal manure were applied only to arable land (irrigated and

215 rainfed).

216 To run the model, monthly $\mathrm{C}$ inputs derived from plant residues and from animal

217 manure application were assigned to each of the spatial units according to land use. The

218 splitting ratios for DPM and RPM (DPM/RPM) were assigned differently for each

219 agricultural system. We assumed 49\% DPM, 49\% RPM, and 2\% humified organic matter

220 for manure and 59\% DPM and 41\% RPM $(\mathrm{DPM} / \mathrm{RPM}=1.44)$ for both irrigated and

221 rainfed crops based on Coleman and Jenkinson (1996). Regarding woody crops, and to

222 refine the data, we considered a better resistance to degradation than cropping systems 
223 (50\% DPM and 50\% RPM, DPM/RPM = 1), since woody crops contains higher lignin 224 content.

225 Water inputs from irrigation were also taken into account and added to monthly 226 precipitation in the weather file of the model and managed as baseline conditions. Average

227 irrigation doses of the different crops applied in the baseline climatic scenario were 228 obtained from Lecina et al. (2010), and rates were calculated considering the different 229 cropping areas. For the climate change scenarios, we chose to keep the same irrigation 230 patterns and rates as in the baseline climatic scenario. Although we acknowledge the 231 robustness that an adjustment of the irrigation strategies could bring to climate change 232 scenarios (Zhao et al., 2015), we decided to have a conservative assumption (i.e., 233 unchanged irrigation) due to large uncertainties (Wada et al., 2013) associated with 234 choosing a specific irrigation adjustment (Klove et al., 2014). Indeed, for this region (the 235 Ebro region), there have been many studies that have shown large variation in the range 236 (3-20\%) of irrigation need predictions (Iglesias and Minguez, 1997; Jorge and Ferreres, 237 2001; Döll, 2002; Fischer et al., 2007; Rey et al., 2011; von Gunten et al., 2015).The large 238 uncertainty in these estimates is not only due to climate models and scenarios used 239 (García-Vera, 2013), but also to factors in relation with future human impacts on land use 240 changes and demands (Pulido-Velazquez et al., 2015). For example, the future choice of 241 crop types by farmers as a response to climatic change or social and economic factors (von 
242 Gunten et al., 2015) is likely to play an important role in constraining future irrigation

243 water demand (Wada et al., 2013).

244 RothC initialization requires $\mathrm{C}$ pools to be sized. For regional-scale simulation, $\mathrm{C}$ pool

245 quantification is infeasible. As an alternative method, we used the pedotransfer functions

246 established by Weihermüller et al. (2013), which have been shown to be helpful in

247 initializing the reactive pools of the RothC model. These functions are based on easily

248 available variables such as SOC stocks and clay content, which, for this study, were

249 derived from Rodríguez Martín et al. (2016).

250 Since the regional simulation is computationally intensive and time consuming due to

251 the combination of a large number of runs for each polygon and a large number of

252 polygons, we developed a VBA (Visual Basic for Applications)-based program in Excel to

253 simulate changes in SOC stocks simultaneously for the different polygons for the period of 2542010 to 2100.

\section{Climate Change Scenarios}

256 Climate change projections suggest that Mediterranean Spain is likely to become one

257 of the areas in Europe that will be more severely affected by climate change. Christensen et

258 al. (2007), for example, showed that the highest climate change impact would affect the

259 Mediterranean part of Spain, with a temperature raise of $>6^{\circ} \mathrm{C}$. As a summary of the 
260 climate data used in this study, all climate change scenarios predict a decrease in

261 precipitation and an increase in mean air temperature in the following order (Fig. 1,

262 Supplemental Fig. S3): CGCM2-B2 < CGCM2-A2 < ECHAM4-B2 < ECHAM4-A2.

263 Although there is an overall decrease in monthly precipitation of 10.6 and $9.5 \mathrm{~mm}$ under

264 ECHAM4-A2 and ECHAM4-B2 scenarios and 3 and $4 \mathrm{~mm}$ under CGCM2-B2 and

265 CGCM2-A2 scenarios, respectively, the average monthly temperature rises from $2^{\circ} \mathrm{C}$ under

266 CGCM2-B2 to $7^{\circ} \mathrm{C}$ under ECHAM4-A2. Not only do climate change scenarios show

267 lower annual precipitation, but they also indicate different annual precipitation distribution

268 than the baseline scenario (Fig. 1). The climate models producing the largest changes in

269 climate (ECHAM4-B2 and ECHAM4-A2) predict a significant decrease in precipitation

270 during the typical precipitation season (spring and autumn) (Fig. 1). The decadal

271 distribution pattern of annual precipitation is significantly modified among the climate

272 change scenarios compared with the current climatic conditions (Supplemental Fig. S3).

273 However, the annual and decadal temperature distribution are not modified by climate

274 change (Fig. 1, Supplemental Fig. S3). Finally, when we compare the climate projections

275 used in our study for the different Aragon climatic regions, we can observe that the Ebro

276 depression in the central area of Aragon showed the highest temperatures under climate

277 change conditions and the smallest average precipitation decrease compared with the other 
278 two mountainous areas (the Pyrenees mountains in the north and the Iberian mountains in

279 the south, Supplemental Table S1).

\section{Soil Management Scenarios}

281 To enhance SOC stocks under climate change conditions during the simulation period

282 of 2010 to 2100 , we simulated alternative soil management scenarios, such as NT and

283 vegetation cover for rainfed and woody crop systems, respectively. For NT practices, we

284 considered two livestock future projections for livestock numbers and, thus, for animal

285 manure. Then, we analyzed the effect of these practices (Supplemental Table S2) under the

286 most extreme climate change scenario (ECHAM4-A2).

287 No-tillage has been shown to be an interesting strategy for rainfed systems of Aragon

288 in terms of SOC increase (Álvaro-Fuentes et al., 2008). However, the NT effect of

289 reducing organic matter decomposition rates cannot be directly simulated with the RothC

290 model. Therefore, we indirectly considered NT practices by accounting the impacts of NT

291 on plant residue data (Nemo et al., 2017). On the basis of experimental studies from the

292 zone (Lampurlanés and Cantero-Martínez, 2006; Plaza-Bonilla et al., 2017), we made the

293 assumption that plant C input at sowing was greater under NT (60\%) than under deep or

294 minimum tillage. 
295 Since future projections for livestock production are subject to a large degree of 296 uncertainty (Thornton, 2010; van Grinsven et al., 2015), we explored the potential range of

297 livestock change by both an increase and a decrease in animal numbers ( $\square 20 \%$ animal

298 production). Both scenarios are supposed to match potential demand-driven trends, the first

299 by rising income and urbanization of the population, and the second if the population has a

300 concern over eating animal products. A linear increase or decrease in animal numbers for

301 the 2010 to 2030 period and a stable situation for the 2030 to 2100 period were assumed

302 for this study.

303 The use of vegetation cover in olive groves could be an efficient strategy to increase

304 SOC sequestration and reduce erosion impacts (Gómez-Muñoz et al., 2014). This strategy

305 is especially relevant in the context of Mediterranean olive groves, as it has been confirmed

306 by some studies already (e.g., Álvarez et al., 2007). Accordingly, for woody crops, we

307 simulated soil management consisting of a natural vegetation cover and assumed a residue

308 of dry biomass of $1570 \mathrm{~kg} \mathrm{ha}^{-1} \mathrm{yr}^{-1}$ based on Gómez-Muñoz et al. (2014) and monthly C

309 inputs of $0.06 \mathrm{Mg} \mathrm{ha}^{-1}$ (assuming $45 \% \mathrm{C}$ content in dry matter). 


\section{RESULTS AND DISCUSSION}

\section{Regional Soil Organic Carbon Changes under Climate Scenarios}

312 Results showed an increase in total SOC stocks in Aragon for the 2010 to 2100 period

313 under baseline and climate change conditions (Fig. 2). To explore the potential for SOC

314 sequestration, simulations were performed under the assumption that all plant residues

315 were returned to the soil. Therefore, the observed increase can be partly explained by the

316 biomass returns and $\mathrm{C}$ input levels considered during the simulation period, mainly due to

317 pruning in woody crop systems (Sofo et al., 2005), crop residues in both rainfed and

318 irrigated systems (Powlson et al., 2011), and the climate change conditions in both

319 mountainous zones. Comparing SOC content evolution among climate scenarios, the

320 greatest enhancement in SOC content was observed in the baseline scenario (assuming no

321 climate change conditions), with SOC values increasing from 49.5 (2010) to $75.2 \mathrm{Mg} \mathrm{C}$

$322 \mathrm{ha}^{-1}$ (2100). In comparison, in all the climate change scenarios, the potential for SOC

323 sequestration decreased, with the lowest SOC increase found in the two ECHAM4 climate

324 scenarios (A2 and B2, 68.5 and $68 \mathrm{Mg} \mathrm{C} \mathrm{ha}^{-1}$, respectively), (Fig. 2). For CGCM2-A2 and

325 CGCM2-B2 scenarios, intermediate SOC values were observed at the end of the simulation

326 period (2100), with 70.2 and $70.8 \mathrm{Mg} \mathrm{C} \mathrm{ha}^{-1}$, respectively (Fig. 2). The lowest SOC

327 sequestration rates found in ECHAM4-A2 and ECHAM4-B2 scenarios (Fig. 2) were 
associated climatically with the greatest decline in precipitation rates and rise in

329 temperature (Supplemental Table S3).

330 It is worth noting that ECHAM4-A2 showed slightly larger SOC contents than

331 ECHAM4-B2, mainly in the last five decades of the simulation period (Fig. 2). In that

332 period, average temperatures were consistently higher under the ECHAM4-A2 scenario

333 than under ECHAM4-B2, whereas precipitation rates were slightly lower (Supplemental

334 Fig. S3), thus suggesting the combined effect of both climatic variables on soil moisture

335 deficit and consequently on SOC evolution. In line with our results, Smith et al. (2005)

336 underlined the combined effects of climate change on SOC dynamics as a balance between

337 temperature increase and soil moisture variation for the entire European agricultural

338 surface.

339 The climate change conditions of the scenarios considered resulted in slight differences

340 in SOC sequestration rates. The estimated decrease in potential SOC sequestration rates

341 under climate change conditions could be mainly associated with the higher temperature

342 predicted in the climate change scenarios (Supplemental Table S3), which could have

343 triggered greater decomposition rates (Davidson and Janssens, 2006). Hence, the effect of

344 average temperature increases of 6 to $7^{\circ} \mathrm{C}$ (Fig. 1a) in the whole Aragon region would be

345 linked to the lowest SOC estimated under ECHAM4 scenarios. However, lower

346 precipitation and reduced soil moisture can slow down SOC decomposition (Skopp et al., 
347 1990), thus counteracting the higher temperature influence. These two combined effects

348 would explain the slight differences in SOC evolution observed between ECHAM4 and

349 CGCM2. In the CGCM2 scenarios, the average temperature rise was moderate $\left(2-3^{\circ} \mathrm{C}\right)$,

350 but the precipitation decrease was also moderate, which involves a smaller restriction on

351 SOC decomposition rate due to soil moisture deficit. As a result, potential SOC

352 sequestration rates simulated in the CGCM2 scenarios were just slightly higher than in the

353 ECHAM4.

354 The spatial distribution of SOC levels in 2100 in the ECHAM4-A2 scenario showed

355 lower SOC contents than those found under baseline conditions (Fig. 3). For example, in

356 the humid zones (Pyrenees and Iberian zones, located in the north and south parts of

357 Aragon, respectively), the model predicted a decrease of total surface with SOC contents

$358>97 \mathrm{Mg} \mathrm{C} \mathrm{ha}^{-1}$ in 2100 (Fig. 3). Similarly, in the central region of the study area, where the

359 drier conditions prevailed ( $<400 \mathrm{~mm}$ precipitation), the area with SOC levels $<57 \mathrm{Mg} \mathrm{C}$

$360 \mathrm{ha}^{-1}$ also increased (Fig. 3). These results provide an indication of the effects of warming

361 on SOC dynamics.

362 Our results suggest that the decrease in soil moisture seems to constrain soil microbial

363 activity, this effect being very clear in rainfed cropping systems. In fact, the RothC water

364 balance results showed that, for about half of the year, microbial activity was reduced up to

$36590 \%$ compared with the rest of the year. Compared with another study applied in the same 
366 area (Álvaro-Fuentes et al., 2012a) and using a different model (Century), however, this

367 moisture effect was the major factor controlling SOC dynamics. The difference between

368 results from different models is likely explained by differences in two parameter values.

369 The rate modifier for temperature parameter value is always higher in RothC than in the

370 Century model, and the opposite is found for the rate modifier for moisture value (Falloon

371 and Smith, 2002). The underlying uncertainty in the response of soil $\mathrm{C}$ to soil moisture is

372 generally attributed to the associated uncertainty in the relationship between soil moisture

373 and soil microbial processes (Falloon et al., 2011). This relationship is complex and

374 depends on several processes, particularly oxygen diffusion and biochemical processes. In

375 RothC, the soil moisture reduction depends on soil clay content, precipitation, and

376 evaporation rate (Bauer et al., 2008), which underestimates the influence of other possible

377 factors. A better understanding of the relationship between soil moisture and SOC

378 decomposition is needed to reduce this uncertainty and improve our confidence in SOC

379 changes under climate change predictions.

380 According to variability within climate change scenarios and considering the different

381 agricultural systems modeled, irrigated crops showed the highest SOC increase at the end

382 of the simulation period for all climate scenarios (Table 1). For all climate scenarios,

383 rainfed crops showed smaller increases in C sequestration than irrigated crops (Table 1).

384 This could be associated with the limited amount of harvest residue in rainfed conditions, 
385 especially after drought periods in semiarid Mediterranean areas (Navarrete et al., 2009),

386 and with the higher water supply in irrigated crops, mainly by irrigation, as it increases

387 SOC stocks through greater plant residue (Gillabel et al., 2007).

388 The smallest SOC increase was observed in the vineyard and olive grove cropping

389 systems for all the climate scenarios. Indeed, olive groves showed SOC losses under all

390 climate change scenarios, reaching $-7.5 \mathrm{Mg} \mathrm{ha}^{-1}$ (Table 1) under the ECHAM4-A2

391 scenario. In Mediterranean areas, olive plantations are traditionally cultivated in

392 nonirrigated soils with low fertility, with low planting densities and intensive tillage,

393 making them more susceptible to SOC losses (Nieto et al., 2010).

394 The highest SOC stock can be explained by greater C input in irrigated crops than in

395 rainfed and woody crops, and a lower temperature in the baseline scenario versus climate

396 change conditions. It therefore seems likely that the model is sufficiently sensitive to the C

397 input and temperature.

398 Climate change could alter $\mathrm{C}$ inputs, as changes in temperature, precipitation, and

399 atmospheric $\mathrm{CO}_{2}$ levels could affect net primary production (Falloon et al., 2007). The

400 RothC model does not include changes in these $\mathrm{C}$ net primary production-related inputs

401 (Meersmans et al., 2013), constraining the reliability of SOC stock changes estimations. In

402 Mediterranean conditions, it is unlikely that crop yield or C inputs would increase under 
403 climate change conditions with higher temperature and lower water availability (Wan et

404 al., 2011). Higher atmospheric $\mathrm{CO}_{2}$ has the potential to increase crop yield as a result of

405 enhanced crop photosynthesis (Högy et al., 2009; Álvaro-Fuentes et al., 2012a) and an

406 increase in water use efficiency via lower stomatal conductance (Morgan et al., 2004).

407 However, plant quality and quantity respond not only to concentrations of $\mathrm{CO}_{2}$ but also to

408 changes in temperature and precipitation patterns (driven by changes in the occurrence of

409 extreme climatic events or changes in average conditions), and stressors such as ozone

410 concentration or salinity. The extent to which these variables can affect crop yield will

411 depend on complex interactions between these variables, nutrient availability, type of

412 species (e.g., $\mathrm{C}_{3}$ vs. $\mathrm{C}_{4}$ species, herbaceous vs. woody species, etc.), and the indirect effect

413 of climate change on forage pests and diseases. Moreover, although out of the scope of this

414 study, some possible adaptation practices including improvement of crop varieties,

415 implementation of technology change, and adjusting the harvest date could offset the

416 declining trend of crop yields and hence of $\mathrm{C}$ inputs.

417 Soil Organic Carbon Changes under Management Scenarios

418 Considering the warmest climate change scenario (ECHAM4-A2), the two NT

419 scenarios stored almost more than twofold the SOC stored in the control during the study

420 period (Fig. 4). Both livestock scenarios showed similar levels of SOC sequestered, with 
42143 and $42.8 \mathrm{Mg} \mathrm{C} \mathrm{ha}^{-1}$ for the increased and decreased livestock projections, respectively

422 (Fig. 4). Hence, the decrease or increase in manure (20\% until 2030) did not significantly

423 affect the SOC content in agricultural soils of Aragon during the period of 2010 to 2100.

424 This might be explained by the fact that the amount of animal manure assumed in our

425 study region was much lower than the total $\mathrm{C}$ inputs from the plant residues.

$426 \quad$ Navarrete et al. (2009) found an annual average sequestration rate ranging between 0.4

427 and $0.5 \mathrm{Mg} \mathrm{C} \mathrm{ha}^{-1}$ under Mediterranean conditions and NT soil management, which is

428 similar to the values that we have observed in this study $\left(0.47 \mathrm{Mg} \mathrm{C} \mathrm{ha}^{-1}\right)$ over the

429 simulated 90 -yr period. The average annual sequestration rate achieved in our case study is

430 included in the range values of the mentioned study, since in our case, we are assuming

431 total incorporation of residues while considering the warming conditions of the ECHAM4-

432 A2 climate change scenario. Similarly, referring to woody crop systems, vegetation cover

433 under the ECHAM4-A2 climate change scenario quadrupled the SOC sequestration rate

434 compared with the unchanged soil management (control) (Fig. 5).

435 According to these findings, both soil management practices of NT in rainfed and 436 vegetation cover crops in woody crops are effective in enhancing SOC stocks in 437 Mediterranean Spain under climate change conditions (Supplemental Fig S4). 
439 We evaluated the model results against measured data only for the baseline SOC stock

440 predictions, as the RothC model is not able to simulate crop yields. Considering that such

441 SOC data are scarce at the scale of the studied region (Aragon scale), we used the data

442 from Álvaro-Fuentes et al. (2009), which measured SOC sequestration rates in field

443 experiments in Aragon. Under the baseline scenario, in rainfed systems, the RothC model

444 simulated SOC sequestration rates of $21.4 \mathrm{Mg} \mathrm{C} \mathrm{ha}^{-1}$ during a period of $90 \mathrm{yr}$, which is

445 equivalent to $0.23 \mathrm{Mg} \mathrm{Cha}^{-1} \mathrm{yr}^{-1}$ (Table 1). We observed a slight difference between mean

446 simulated and measured values (0.23 and $0.18 \mathrm{Mg} \mathrm{C} \mathrm{ha}^{-1} \mathrm{yr}^{-1}$, respectively). This is due to

447 the fact that we are considering the maximum potential of the SOC sequestration assuming

448 a total incorporation of $\mathrm{C}$ inputs, thus proving that RothC model results agree reasonably

449 with the expected and measured ranges. However, future research efforts should be made

450 using more and larger, reliable datasets (e.g., under more management practices and

451 cropping systems) to increase our confidence in the RothC results under different

452 management practices and cropping systems.

453 Climate change is expected to affect crops responses in many and complex ways (e.g.,

454 average yields, plant quality). For example, whereas water shortage has undoubtedly a

455 negative effect on yield, this can be partly offset, as has been found in common crops like

456 wheat (Challinor et al. et al., 2014; Ferrise et al., 2016), by photosynthetic stimulation and 
457 enhanced water use efficiency through stomatal closure as a result of enhanced $\mathrm{CO}_{2}$

458 atmospheric concentration.

459 For the Iberian Peninsula, most studies that do not consider adaptation measures predict

460 a reduction in crop rainfed dry matter yields for all climate change projections (e.g., 20\%:

461 Ciscar et al., 2014), being especially severe for the end of the 21 st century (e.g., wheat:

462 Hernandez-Barrera et al., 2017) due to increased drought duration and intensity.

463 Provided that attempting to robustly predict changes in crop yields (i) is out of the

464 scope of this study, (ii) involves complex methodologies and uncertain assumptions (e.g., a

465 limited set of available field data), and (iii) depends on other farmer decisions (e.g.,

466 technology improvements: Iglesias and Quiroga., 2007; changes in varieties, planting

467 times, irrigation, and residue management: Challinor et al., 2014), we assumed that climate

468 change did not affect crop yields and, subsequently, the amount of $\mathrm{C}$ plant residue inputs to

469 the soil compared with the baseline scenario. In recognition of this limitation, for

470 illustration purposes, we made a simple scenario test to see the SOC model response to

471 changes in crop yields in representative rainfed cropping (wheat) systems in our study

472 region. For this exercise, we used the range of potential yield change ( $\square 30 \%)$ found in the

473 study of Iglesias et al. (2000) and explored the SOC changes as a result of steps of $10 \%$

474 change under CGCM climate change scenarios. Results from this test indicate that each 
$47510 \%$ change in dry matter yields resulted in 5\% change in SOC storage, compared with the

476 control scenario (with no $\mathrm{C}$ input change) at the end of the simulation period

477 (Supplemental Fig. S5). These results certainly confirm the importance that future studies

478 attempt to focus on $\mathrm{C}$ input effects variations associated with uncertainty in dry matter

479 yields in climate change scenarios.

480 Qualitative Analysis of Uncertainty

481 Uncertainty related to this work may be ascribed to the model applied, the initial size

482 characterization of SOC fractions, and the nonavailability of some data at the temporal or

483 spatial levels. Indeed, for most of the parameters (e.g., inputs of irrigation water, HI),

484 modeling was performed according to the most common practices of the study area.

485 Despite RothC performance shown in many studies (Coleman et al., 1997; Falloon and

486 Smith, 2002; Falloon et al., 2006), we have to take into account some limitations of the

487 model and of the procedure applied. The model uses a monthly time step to calculate total

488 SOC, which may overlook some processes of SOC changes occurring at daily timescale.

489 The proposed regional analysis is based on a spatial division of the agricultural Aragon

490 territory into different geographical areas that share a set of specific parameters (e.g.,

491 climate, soil properties, and land use). The model runs each one of the spatial units

492 independently so that possible interaction (e.g., water and soil erosion, horizontal flows) 
493 between neighboring polygons is ignored (Paustian et al., 1997). Regarding erosion, RothC

494 does not consider the $\mathrm{C}$ lost by this phenomenon, which may become a limitation in certain

495 areas where soil loss is more accentuated (Martínez-Mena et al., 2008). Changes in soil

496 management and $\mathrm{C}$ input values throughout the study period were not considered, which

497 brings another source of uncertainty. However, assuming constant soil management

498 conditions during simulation period allows isolated analysis of the impact of climate

499 change on SOC sequestration. Finally, regional climate change projections are subject to

500 several sources of uncertainty associated with global general circulation models and

501 regionalization techniques.

\section{Conclusions}

503 This study has shown significant variations in the SOC sequestration capacity among

504 the different agricultural systems in a representative Spanish area under climate change

505 conditions. Regarding the different agricultural systems tested, whereas irrigated crops

506 resulted in largest SOC sequestration potential even under the most extreme scenario

507 (ECHAM4), rainfed crops, vineyards, and olive groves showed the lowest potential. These

508 differences are probably due to low productivity of certain rainfed agricultural systems that

509 led to a reduction in harvest residue matter, suggesting that $\mathrm{C}$ inputs must be the greatest

$510 \quad$ SOC driver. 
511 According to comparisons among climate change scenarios, temperature increase and

512 rainfall decrease will generally lead to a decline in SOC content. Indeed, ECHAM4

513 scenarios predicted the greatest impacts on SOC sequestration for the next $90 \mathrm{yr}$ due to a

514 high temperature increase.

515 No-tillage, in the case of rainfed crops, and vegetation cover, for olive groves and other

516 woody crops, were the alternative management strategies to alleviate climate change

517 effects and SOC loss. These changes in management enhanced the amount of SOC

518 sequestered and were found to be effective strategies in reducing $\mathrm{CO}_{2}$ emissions and

519 increasing soil potential to sequester $\mathrm{C}$ under future climate change conditions.

520 Supplemental Material

$521 \quad$ Five supplemental figures and three supplemental tables are available online.

\section{ACKNOWLEDGMENTS}

523 We gratefully acknowledge the financial support of the Fundación Cándido de Iturriaga y Maria del

524 Dañobeitia and the Mediterranean Agronomic Institute of Zaragoza, International Centre for Advanced

525 Mediterranean Agronomic Studies (IAMZ-CIHEAM).

526 REFERENCES

527 Adams, R.C., F.S. MacLean, J.K. Dixon, F.M. Bennett, G.I. Martin, and R.C. Lough. 1951. The utilization of 528 organic wastes in N. Z.. N. Z. Eng. 6:396-424. 
529 Aguilera, E., G. Guzman, and A. Alonso. 2015. Greenhouse gas emissions from conventional and organic

530 cropping systems in Spain. II. Fruit tree orchards. Agron. Sustain. Dev. 35:725-737.

531 doi:10.1007/s13593-014-0265-y

532 Allen, R.G., Pereira, L.S., Raes, D. 1998. Guidelines for computing crop water requirements: Crop 533 evapotranspiration. Irrig. Drain. Paper 56. FAO, Rome.

534 Álvarez, S., M.A. Soriano, B.B. Landa, and J.A. Gómez. 2007. Soil properties in organic OG compared with 535 that in natural areas in a mountainous landscape in southern Spain. Soil Use Manage. 23:404-416. 536 doi:10.1111/j.1475-2743.2007.00104.x

537 Álvaro-Fuentes, J., M. V. López, J.L. Arrúe, D. Moret, and K. Paustian. 2009. Tillage and cropping effects 538 on soil organic carbon in Mediterranean semiarid agroecosystems: Testing the Century model. Agric. 539 Ecosyst. Environ. 134(3-4): 211-217. doi: 10.1016/j.agee.2009.07.001

541 Álvaro-Fuentes, J., M. Easter, and K. Paustian. 2012a. Climate change effects on organic carbon storage in 542 agricultural soils of northeastern Spain. Agric. Ecosyst. Environ. 155:87-94. $543 \quad$ doi:10.1016/j.agee.2012.04.001

544 Álvaro-Fuentes, J., F. Joaquín Morell, D. Plaza-Bonilla, J. Luis Arrúe, and C. Cantero-Martínez. 2012b. 545 Modelling tillage and nitrogen fertilization effects on soil organic carbon dynamics. Soil Tillage Res. $546 \quad$ 120:32-39. doi:10.1016/j.still.2012.01.009

547 Álvaro-Fuentes, J., M.V. López, C. Cantero-Martínez, and J.L. Arrúe. 2008. Tillage effects on soil organic 548 carbon fractions in Mediterranean dryland agroecosystems. Soil Sci. Soc. Am. J. 72:541-547. 549 doi:10.2136/sssaj2007.0164 
550 Álvaro-Fuentes, J., F.J. Morell, E. Madejon, J. Lampurlanes, J.L. Arrue, and C. Cantero-Martínez. 2013. Soil

551 biochemical properties in a semiarid Mediterranean agroecosystem as affected by long-term tillage and

$552 \quad$ N fertilization. Soil Tillage Res. 129:69-74. doi:10.1016/j.still.2013.01.005

553 Bauer, J., M. Herbst, J.A. Huisman, L. Weihermüller, and H. Vereecken. 2008. Sensitivity of simulated soil

554 heterotrophic respiration to temperature and moisture reduction functions. Geoderma 145(1-2): 17-

555 27.doi: $10.1016 /$ j.geoderma.2008.01.026

556

557 Berenguer, P., F. Santiveri, J. Boixadera, and J. Lloveras. 2009. Nitrogen fertilisation of irrigated maize

558 under Mediterranean conditions. Eur. J. Agron. 30:163-171. doi:10.1016/j.eja.2008.09.005

559 Bleuler, M., R. Farina, R. Francaviglia, R. Napoli, and A. Marchetti. 2017. Modelling the impacts of different

560 carbon sources on the soil organic carbon stock and $\mathrm{CO}_{2}$ emissions in the Foggia province (southern

$561 \quad$ Italy). Agric. Syst. 157:258-268. doi:10.1016/j.agsy.2017.07.017

562 Brunet, M., M.J. Casado, M. de Castro, P. Galán, J.A. López, J.M. Martín, et al. 2008. Generación de

563 escenarios regionalizados de cambio climático para España. Agencia Estatal Meteorol., Min. Medio

564 Ambiente, Medio Rural y Marino, Gob. España, Madrid.

565 Challinor, A.J., J. Watson, D.B. Lobell, S.M. Howden, D.R. Smith, and N. Chhetri. 2014. A meta-analysis of

566 crop yield under climate change and adaptation. Nat. Clim. Chang. 4:287-291. 567 doi: $10.1038 /$ nclimate2153

568 Christensen, J.H., T.R. Carter, M. Rummukainen, and G. Amanatidis. 2007. Evaluating the performance and 569 utility of regional climate models: The PRUDENCE project. Clim. Change 81:1-6. doi:10.1007/s10584- 
571 Ciscar, J., A. Soria, C. Lavalle, F. Raes, M. Perry, F. Nemry, et al. 2014. Climate impacts in Europe: The $572 \quad$ JRC Peseta II Project. Publ. Office Eur. Union, Luxembourg.

573 Coleman, K., and D.S. Jenkinson. 1996. RothC-26.3: A model for the turnover of carbon in soil. In: D.S.

574 Powlson, P. Smith, and J.U. Smith, editors, Evaluation of soil organic matter models using existing,

575 long-term datasets. NATO ASI Ser. I. Springer-Verlag, Heidelberg, Germany. p. 237-246.

576 doi:10.1007/978-3-642-61094-3_17

577 Coleman, K., D.S. Jenkinson, G.J. Crocker, P.R. Grace, J. Kffr, M.K. Srschens, et al. 1997. Simulating trends

578 in soil organic carbon in long-term experiments using RothC-26. 3. Geoderma 81:29-44.

579 doi:10.1016/S0016-7061(97)00079-7

580 Cuadrat, J.M. 1999. El clima de Aragón. In J.L. Peña, L.A. Longares and M. Sanchez, editors. Geografía

581 física de Aragon. Aspectos generales y temáticos. CAI 100, Zaragoza. p.109.

582 Daudén, A., and D. Quilez. 2004. Pig slurry versus mineral fertilization on corn yield and nitrate leaching in 583 a Mediterranean irrigated environment. Eur. J. Agron. 21:7-19. doi:10.1016/S1161-0301(03)00056-X

584 Daudén, A., D. Quilez, and C. Martinez. 2004. Residual effects of pig slurry applied to a Mediterranean soil 585 on yield and $\mathrm{N}$ uptake of a subsequent wheat crop. Soil Use Manage. 20:156-162. 586 doi:10.1079/SUM2003230

587 Davidson, E.A., and I.A. Janssens. 2006. Temperature sensitivity of soil carbon decomposition and feedbacks 588 to climate change. Nature 440:165-173. doi:10.1038/nature04514

589 De Vita, P., E. Di Paolo, G. Fecondo, N. Di Fonzo, and M. Pisante. 2007. No-tillage and conventional tillage 590 effects on durum wheat yield, grain quality and soil moisture content in southern Italy. Soil Tillage Res. 
592 DGA. 2012. Agricultural statistical yearbooks of Aragon 2012. (In Spanish.) Gob. Aragon, Zaragoza, Spain.

593 http://www.aragon.es/DepartamentosOrganismosPublicos/Departamentos/DesarrolloRuralSostenibilidad

594 /AreasTematicas/EstadisticasAgrarias/ci.ANUARIO_ESTADISTICO_AGRARIO.detalleDepartamento?

595 channelSelected=1cfbc8548b73a210VgnVCM100000450a15acRCRD (accessed 9 Oct. 2015).

596 Di Blasi, C., V. Tanzi, and M. Lanzetta. 1997. A study on the production of agricultural residues in Italy.

597 Biomass Bioenergy 12:321-331. doi:10.1016/S0961-9534(96)00073-6

598 Döll, P. 2002. Impact of climate change and variability on irrigation requirements: A global perspective.

599 Clim. Change 54:269-293.

600 Erice, G., A. Sánz-Saez, A. Urdiain, J.L. Araus, J.J. Irigoyen, and I. Aranjuelo. 2014. Harvest index

601 combined with impaired $\mathrm{N}$ availability constrains the responsiveness of durum wheat to elevated $\mathrm{CO}_{2}$

602 concentration and terminal water stress. Funct. Plant Biol. 41:1138-1147. doi:10.1071/FP14045

603 Falloon, P., C.D. Jones, M. Ades, and K. Paul. 2011. Direct soil moisture controls of future global soil carbon

604 changes: An important source of uncertainty. Global Biogeochem. Cycles 25(3):1-14.

605 doi:10.1029/2010GB003938

606 Falloon, P., C.D. Jones, C. Eduardo, R. Al-Adamat, P. Kamoni, T. Bhattacharyya, et al. 2007. Climate

607 change and its impact on soil and vegetation carbon storage in Kenya, Jordan, India and Brazil. Agric.

$608 \quad$ Ecosyst. Environ. 122:114-124. doi:10.1016/j.agee.2007.01.013

609 Falloon, P., and P. Smith. 2002. Simulating SOC changes in long-term experiments with RothC and

610 CENTURY: Model evaluation for a regional scale application. Soil Use Manage. 18:101-111.

611 doi:10.1111/j.1475-2743.2002.tb00227.x 
612 Falloon, P., P. Smith, R.I. Bradley, R. Milne, R. Tomlinson, D. Viner, et al. 2006. RothCUK: A dynamic

613 modelling system for estimating changes in soil C from mineral soils at 1-km resolution in the UK. Soil

$614 \quad$ Use Manage. 22:274-288. doi:10.1111/j.1475-2743.2006.00028.x

615 Farina, R., A. Marchetti, R. Francaviglia, R. Napoli, and C. Di Bene. 2017. Modeling regional soil C stocks

616 and $\mathrm{CO}_{2}$ emissions under Mediterranean cropping systems and soil types. Agric. Ecosyst. Environ.

617 238:128-141. doi:10.1016/j.agee.2016.08.015

618 Ferrise, R., G. Trombi, M. Moriondo, and M. Bindi. 2016. Climate change and grapevines: A simulation

619 study for the Mediterranean basin. J. Wine Econ. 11: 88-104. doi:10.1017/jwe.2014.30

620 Fischer, G., F.N. Tubiello, H. van Velthuizen, and D.A. Wiberg. 2007. Climate change impacts on irrigation

621 water requirements: Effects of mitigation, 1990-2080. Technol. Forecast. Soc. Change 74:1083-1107.

622 doi:10.1016/j.techfore.2006.05.021

623 Frank, S., E. Schmid, P. Havlík, U.A. Schneider, H. Böttcher, and J. Balkovi. 2015. The dynamic soil organic

624 carbon mitigation potential of European cropland. Glob. Environ. Change 35:269-278.

625 doi:10.1016/j.gloenvcha.2015.08.004

626 García-Vera, M.A. 2013. The application of hydrological planning as a climate change adaptation tool in the

627 Ebro basin. Int. J. Water Resour. Dev. 29:219-236. doi:10.1080/07900627.2012.747128

628 GEA. 2000. Gran enciclopedia Aragonesa. DiCom Medios. http://www.enciclopedia629 aragonesa.com/voz.asp?voz_id=828 (accessed Oct. 2015).

630 Gillabel, J., K. Denef, J. Brenner, R. Merckx, and K. Paustian. 2007. Carbon sequestration and soil 631 aggregation in center-pivot irrigated and dryland cultivated farming systems. Soil Sci. Soc. Am. J. 632 71:1020-1028. doi:10.2136/sssaj2006.0215 
633 Gómez-Muñoz, B., D.J. Hatch, R. Bol, and R. García-Ruiz. 2014. Nutrient dynamics during decomposition

634 of the residues from a sown legume or ruderal VC in an olive oil orchard. Agric. Ecosyst. Environ.

$635 \quad 184: 115-123$. doi:10.1016/j.agee.2013.11.020

636 González, J.F., C.M. González-Garcia, A. Ramiro, J. Ganan, J. González, E. Sabio, et al. 2005. Use of

637 almond residues for domestic heating. Study of the combustion parameters in a mural boiler. Fuel

638 Process. Technol. 86:1351-1368. doi:10.1016/j.fuproc.2005.01.022

639 Haddaway, N.R., K. Hedlund, L.E. Jackson, T. Kätterer, E. Lugato, I.K. Thomsen, et al. 2015. What are the

640 effects of agricultural management on soil organic carbon in boreo- temperate systems? Environ.

$641 \quad$ Evidence 4:23. doi:10.1186/s13750-015-0049-0

642 Hansen, J., P. Kharecha, M. Sato, V. Masson-Delmotte, F. Ackerman, D.J. Beerling, et al. 2013. Assessing

643 "dangerous climate change": Required reduction of carbon emissions to protect young people, future

644 generations and nature. PLoS ONE 8:e81648. doi:10.1371/journal.pone.0081648

645 Hernandez-Barrera, S., C. Rodriguez-Puebla, and A.J. Challinor. 2017. Effects of diurnal temperature range

646 and drought on wheat yield in Spain. Theor. Appl. Climatol. 129: 503-519. doi:10.1007/s00704-016-

$647 \quad 1779-9$.

648 Högy, P., H. Wieser, P. Köhler, K. Schwadorf, J. Breuer, J. Franzaring, et al. 2009. Effects of elevated CO 2

649 on grain yield and quality of wheat: Results from a 3-year free-air $\mathrm{CO}_{2}$ enrichment experiment. Plant

650 Biol. 11:60-69. doi:10.1111/j.1438-8677.2009.00230.x

651 Iglesias, A., and M.I. Minguez. 1997. Modelling crop-climate interactions in Spain: Vulnerability and 652 adaptation of different agricultural systems to climate change. Mitig. Adapt. Strategies Glob. Change 653 1:273-288. doi:10.1007/BF00517807 
654 Iglesias, A., and S. Quiroga. 2007. Measuring the risk of climate variability to cereal production at five sites 655 in Spain. Clim. Res. 34:47-57. doi:10.3354/cr034047

656 Iglesias, A., C. Rosenzweig, and D. Pereira. 2000. Agricultural impact studies of climate change in Spain:

657 Developing tools for a spatial analysis. Glob. Environ. Change 10:69-80. doi:10.1016/S0959-

$658 \quad 3780(00) 00010-8$

659 Jenkinson, D.S., H.C. Harris, J.H. Ryan, A.M. McNeill, C.J. Pilbeam, and K. Coleman. 1999. Organic matter 660 turnover in a calcareous clay soil from Syria under a two-course cereal rotation. Soil Biol. Biochem. 661 31:687-693. doi:10.1016/S0038-0717(98)00157-6

662 Johnston, A.E., P.R. Poulton, and K. Coleman. 2009. Soil organic matter: Its importance in sustainable 663 agriculture and carbon dioxide fluxes. Adv. Agron. 101:1-57. doi:10.1016/S0065-2113(08)00801-8

664 Jones, C., C. McConnell, K. Coleman, P. Cox, P. Falloon, D. Jenkinson, and D. Powlson. 2005. Global 665 climate change and soil carbon stocks; predictions from two contrasting models for the turnover of 666 organic carbon in soil. Glob. Change Biol. 11:154-166. doi:10.1111/j.1365-2486.2004.00885.x

667 Jorge, J., and E. Ferreres. 2001. Irrigation scenario vs climate change scenario. In: M. India and D. Bonillo, 668 editors, Detecting and modelling regional climate change. Springer, Berlin, Heidelberg. p. 581-592. 669 doi:10.1007/978-3-662-04313-4_49

670 Kaonga, M.L., and K. Coleman. 2008. Modelling soil organic carbon turnover in improved fallows in eastern 671 Zambia using the RothC-26.3 model. For. Ecol. Manage. 256:1160-1166. 672 doi:10.1016/j.foreco.2008.06.017 
673 Klove, B., P. Ala-Aho, G. Bertrand, J.J. Gurdak, H. Kupfersberger, J. Kværner, et al. 2014. Climate change

674 impacts on groundwater and dependent ecosystems. J. Hydrol. 518, Part B:250-266.

675 doi:10.1016/j.jhydrol.2013.06.037

676 Lampurlanés, J., and C. Cantero-Martínez. 2006. Hydraulic conductivity, residue cover and soil surface

677 roughness under different tillage systems in semiarid conditions. Soil Tillage Res. 85:13-26.

678 doi:10.1016/j.still.2004.11.006

679 Lampurlanés, J., D. Plaza-Bonilla, J. Álvaro-Fuentes, and C. Cantero-Martínez. 2016. Long-term analysis of

680 soil water conservation and crop yield under different tillage systems in Mediterranean rainfed

681 conditions. Field Crops Res. 189:59-67. doi:10.1016/j.fcr.2016.02.010

682 Lecina, S., D. Isidoro, E. Playán, and R. Aragues. 2010. Irrigation modernization and water conservation in

683 Spain: The case of Riegos del Alto Aragón. Agric. Water Manage. 97:1663-1675.

684 doi:10.1016/j.agwat.2010.05.023

685 Liu, D.L., K.Y. Chan, and M.K. Conyers. 2009. Simulation of soil organic carbon under different tillage and

686 stubble management practices using the Rothamsted carbon model. Soil Tillage Res. 104:65-73.

687 doi:10.1016/j.still.2008.12.011

688 Lohaus, G., M. Buker, M. Hussmann, C. Soave, and H.W. Heldt. 1998. Transport of amino acids with special

689 emphasis on the synthesis and transport of asparagine in the Illinois low protein and Illinois high protein

$690 \quad$ strains of maize. Planta 205:181-188. doi:10.1007/s004250050310

691 López Arias, M., and J.M. Grau Corbí. 2005. Metales pesados, materia orgánica y otros parámetros de la 692 capa superficial de los suelos agrícolas y de pastos de la España Peninsular. I: Resultados globales. Inst.

693 Nacl. Invest. Tecnol. Agrar. Alimentaria (INIA), Min. Educ. Ciencia, Madrid. 
694 López-Garrido, R., E. Madejón, F. Moreno, and J.M. Murillo. 2014. Conservation tillage influence on carbon

695 dynamics. Pedosphere 24:65-75. doi:10.1016/S1002-0160(13)60081-8

696 MaDGIC. 2014. Trent University Library Maps, Data \& Government Information Centre. Basic Tasks in 697 ArcGIS 10.2.x.

698 MAPAMA. 2009. Anuario de estadística 2008 (datos 2007 y 2008) complete. Min. Agric. Pesca, 699 Alimentación Medio Ambiente. www.magrama.gob.es/es/estadistica/temas/publicaciones/anuario-de700 estadistica/2008/default.aspx (accessed Feb. 2016).

701 MAPAMA. 2011. Min. Agric. Pesca, Alimentación Medio Ambiente. 702 http://www.mapama.gob.es/es/ganaderia/temas/default.aspxaccessed Feb. 2016).

703 MAPAMA. 2013. Encuesta sobre superficies y rendimientos de cultivos (ESYRCE). Min. Agric. Pesca, 704 Alimentación Medio Ambiente. http://www.mapama.gob.es/es/estadistica/temas/estadisticas705 agrarias/agricultura/esyrce/ (accessed Oct. 2016).

706 Martínez-Mena, M., J. López, M. Almagro, C. Boix-Fayos, and J. Albaladejo. 2008. Effect of water erosion 707 and cultivation on the soil carbon stock in a semiarid area of south-east Spain. Soil Tillage Res. 99:119708 129. doi:10.1016/j.still.2008.01.009

709

710

711

712

713

714

Meersmans, J., M.P. Martin, E. Lacarce, T.G. Orton, S.D.E. Baets, M. Gourrat, et al. 2013. Estimation of soil carbon input in France: An inverse modelling approach. Pedosphere 23:422-436. doi:10.1016/S10020160(13)60035-1

Morgan, J.A., D.E. Pataki, C. Körner, H. Clark, S.J. Del Grosso, J.M. Grünzweig, et al. 2004. Water relations in grassland and desert ecosystems exposed to elevated atmospheric $\mathrm{CO}_{2}$. Oecologia 140:11-25. doi:10.1007/s00442-004-1550-2 
715 Mondini, C., K. Coleman, and A.P. Whitmore. 2012. Spatially explicit modelling of changes in soil organic

716 C in agricultural soils in Italy, 2001- 2100: Potential for compost amendment. Agric. Ecosyst. Environ.

717 153:24-32. doi:10.1016/j.agee.2012.02.020

718 Morell, F.J., J. Lampurlanés, J. Álvaro-Fuentes, and C. Cantero-Martínez. 2011. Yield and water use

719 efficiency of barley in a semiarid Mediterranean agroecosystem: Long-term effects of tillage and $\mathrm{N}$

720 fertilization. Soil Tillage Res. 117:76-84. doi:10.1016/j.still.2011.09.002

721 Moret, D., J.L. Arrue, M.V. Lopez, and R. Gracia. 2007. Winter barley performance under different cropping

722 and tillage systems in semiarid Aragon (NE Spain). Eur. J. Agron. 26:54-63.

723 doi:10.1016/j.eja.2006.08.007

724 Nakicenovic, N., J. Alcamo, G. Davis, B. de Vries, J. Fenhann, S. Gaffinn, et al. 2000. Special report on 725 emissions scenarios: A special report of Working Group III of the Intergovernmental Panel on Climate 726 Change. Cambridge Univ. Press, Cambridge, UK.

727 Navarrete, L., J.L. Hernanz, and V. Sa. 2009. Agriculture, Soil carbon sequestration and stratification in a 728 cereal/leguminous crop rotation with three tillage systems in semiarid conditions. Agric. Ecosyst. 729 Environ. 133:114-122. doi:10.1016/j.agee.2009.05.009

730 Nemo, K. Klumpp, K. Coleman, M. Dondini, K. Goulding, A. Hastings, et al. 2017. Soil organic carbon 731 (SOC) equilibrium and model initialisation methods: An application to the Rothamsted Carbon (RothC) 732 model. Environ. Model. Assess. 22:215-229. doi:10.1007/s10666-016-9536-0

733 Nieto, O.M., and J. Castro. 2013. Conventional tillage versus cover crops in relation to carbon fixation in 734 Mediterranean olive cultivation. Plant Soil 365:321-335. doi:10.1007/s11104-012-1395-0 
735 Nieto, O.M., J. Castro, E. Fernandez, and P. Smith. 2010. Simulation of soil organic carbon stocks in a

736 Mediterranean olive grove under different soil-management systems using the RothC model. Soil Use

737 Manage. 26:118-125. doi:10.1111/j.1475-2743.2010.00265.x

738 Panettieri, M., A.E. Berns, H. Knicker, J.M. Murillo, and E. Madejón. 2015. Evaluation of seasonal

739 variability of soil biogeochemical properties in aggregate-size fractioned soil under different tillages.

$740 \quad$ Soil Tillage Res. 151:39-49. doi:10.1016/j.still.2015.02.008

741 Pardo, G., A. del Prado, M. Martínez-Mena, M.A. Bustamante, J.A.R. Martín, J. Álvaro-Fuentes, and R.

742 Moral. 2017. Orchard and horticulture systems in Spanish Mediterranean coastal areas: Is there a real

743 possibility to contribute to $\mathrm{C}$ sequestration? Agric. Ecosyst. Environ. 238:153-167.

$744 \quad$ doi:10.1016/j.agee.2016.09.034

745 Paustian, K., E. Levine, W.M. Post, and I.M. Ryzhova. 1997. The use of models to integrate information and

746 understanding of soil $\mathrm{C}$ at the regional scale. Geoderma 79:227-260. doi:10.1016/S0016-

$747 \quad 7061(97) 00043-8$

748 Paustian, K., B. Bruce, H. Jerry, R. Lal, B. Mccarl, S. McLaughlin, et al. 2004. Agricultural mitigation of

749 greenhouse gases: Science and policy options. Rep. R141 2004. Counc. Agric. Sci. Technol., Ames, IA.

750 Peña, J.L., J.M. Cuadrat, and M. Sánchez. 2002. El clima de la provincia de Teruel. Inst. Estudios

751 Turolenses, Teruel, Spain.

752 Peterson, G.A., A.D. Halvorson, J.L. Havlin, O.R. Jones, D.J. Lyon, and D.L. Tanaka. 1998. Reduced tillage

753 and increasing cropping intensity in the Great Plains conserves soil C. Soil Tillage Res. 47:207-218.

754 doi:10.1016/S0167-1987(98)00107-X 
755 Plaza-Bonilla, D., C. Cantero-Martínez, and J. Álvaro-Fuentes. 2010. Tillage effects on soil aggregation and 756 soil organic carbon profile distribution under Mediterranean semi-arid conditions. Soil Use Manage. 757 26:465-474. doi:10.1111/j.1475-2743.2010.00298.x

758 Plaza-Bonilla, D., J. Álvaro-Fuentes, N. Hansen, C. Cantero-Martinez, and J. Lampurlanés. 2014. Winter 759 cereal root growth and aboveground-belowground biomass ratios as affected by site and tillage system in 760 dryland Mediterranean conditions. Plant Soil 374:925-939. doi:10.1007/s11104-013-1926-3

761 Plaza-Bonilla, D., C. Cantero-Martínez, J. Bareche, J.L. Arrúe, J. Lampurlanés, and J. Álvaro-Fuentes. 2017.

762 Do no-till and pig slurry application improve barley yield and water and nitrogen use efficiencies in 763 rainfed Mediterranean conditions? Field Crops Res. 203:74-85. doi:10.1016/j.fcr.2016.12.008

764 Powlson, D.S., M.J. Glendining, K. Coleman, and A.P. Whitmore. 2011. Implications for soil properties of 765 removing cereal straw: Results from long-term studies. Agron. J. 103:279-287. 766 doi:10.2134/agronj2010.0146s

767 Pulido-Velazquez, M., S. Peña-Haro, A. García-Prats, A.F. Mocholi-Almudever, L. Henriquez-Dole, H. 768 Macian-Sorribes, and A. Lopez-Nicolas. 2015. Integrated assessment of the impact of climate and land 769 use changes on groundwater quantity and quality in the Mancha Oriental system (Spain). Hydrol. Earth $770 \quad$ Syst. Sci. 19:1677-1693. doi:10.5194/hess-19-1677-2015

771 Rey, D., A. Garrido, M.I. Mínguez, and M. Ruiz-Ramos. 2011. Impact of climate change on maize’s water 772 needs, yields and profitability under various water prices in Spain. Spanish J. Agric. Res. 9:1047. 773 doi:10.5424/sjar/20110904-026-11 
774 Rodríguez Martín, J.A., J. Álvaro-Fuentes, J. Gonzalo, C. Gil, J.J. Ramos-Miras, J.M. Grau Corbí, and R.

775 Boluda. 2016. Assessment of the soil organic carbon stock in Spain. Geoderma 264:117-125.

776 doi:10.1016/j.geoderma.2015.10.010

777 Rodríguez Martín, J.A., M. López Arias, and J.M. Grau Corbí. 2009. Metales pesados, materia orgánica y

778 otros parámetros de los suelos agrícolas y de pastos de España. Min. Medio Ambiente Medio Rural

779 Marino, Inst. Nacl. Invest. Tecnol. Agrar. Alimentaria, Madrid.

780 Sanz-Cobeña, A., L. Lassaletta, F. Estellés, A. Del Prado, G. Guardia, D. Abalos, et al. 2014. Yield-scaled

781 mitigation of ammonia emission from N fertilization: The Spanish case. Environ. Res. Lett. 9:125005.

782 doi:10.1088/1748-9326/9/12/125005

783

Skopp, J., M.D. Jawson, and J.W. Doran. 1990. Steady-state aerobic microbial activity as a function of soil-

784 water content. Soil Sci. Soc. Am. J. 54:1619-1625. doi:10.2136/sssaj1990.03615995005400060018x

785

Smith, J., P. Smith, M. Wattenbach, S. Zaehle, R. Hiederer, R.J.A. Jones, et al. 2005. Projected changes in 786 mineral soil carbon of European croplands and grasslands, 1990-2080. Glob. Change Biol. 11:2141787 2152. doi:10.1111/j.1365-2486.2005.001075.x

788

Smith, P., M. Bustamante, H. Ahammad, H. Clark, H. Dong, E.A. Elsiddig, et al. 2014. Agriculture, forestry 789 and other land use (AFOLU). In: O. Edenhofer, et al., editors, Climate change 2014: Mitigation of climate change. Contribution of Working Group III to the fifth assessment report of the Intergovernmental Panel on Climate Change. Cambridge Univ. Press, Cambridge, UK.

792

Sofo, A., V. Nuzzo, A. Maria, C. Xiloyannis, G. Celano, P. Zukowskyj, and B. Dichio. 2005. Net $\mathrm{CO}_{2}$ 793 storage in Mediterranean olive and peach orchards. Sci. Hortic. (Amsterdam) 107:17-24. doi:10.1016/j.scienta.2005.06.001 
795 Thornton, P.K. 2010. Livestock production: Recent trends, future prospects. Philos. Trans. R. Soc., B $796 \quad 365: 2853-2867$. doi:10.1098/rstb.2010.0134

797 UNFCCC. 2014. National inventories submissions 2014. United Nations Framework Conv. Clim. Change.

798 http://unfccc.int/national_reports/annex_i_ghg_inventories/national_inventories_submissions/items/8108

799 .php (accessed Feb. 2016).

800 Vamerali, T., M. Saccomani, S. Bona, G. Mosca, M. Guarise, and A. Ganis. 2003. A comparison of root

801 characteristics in relation to nutrient and water stress in two maize hybrids. Plant Soil 255:157-167.

802 doi:10.1023/A:1026123129575

803 van Grinsven, H.J.M., J.W. Erisman, W. De Vries, and H. Westhoek. 2015. Potential of extensification of

804 European agriculture for a more sustainable food system, focusing on nitrogen. Environ. Res. Lett.

805 10:025002. doi:10.1088/1748-9326/10/2/025002

806 van Keulen, H. 2001. (Tropical) soil organic matter modelling: Problems and prospects. Nutr. Cycl. $807 \quad$ Agroecosyst. 61:33-39. doi:10.1023/A:1013372318868

808 Velazquez-Marti, B., E. Fernandez-Gonzalez, I. Lopez-Cortes, and D.M. Salazar-Hernandez. 2011. 809 Quantification of the residual biomass obtained from pruning of trees in Mediterranean olive groves.

$810 \quad$ Glob. Change Biol. 35:3208-3217.

811 von Gunten, D., T. Wöhling, C.P. Haslauer, D. Merchán, J. Causapé, and O.A. Cirpka. 2015. Estimating 812 climate-change effects on a Mediterranean catchment under various irrigation conditions. J. Hydrol. $813 \quad$ 4:550-570. doi:10.1016/j.ejrh.2015.08.001 
814 Wada, Y., D. Wisser, S. Eisner, M. Flörke, D. Gerten, I. Haddeland, et al. 2013. Multimodel projections and

815 uncertainties of irrigation water demand under climate change. Geophys. Res. Lett. 40:4626-4632.

816 doi:10.1002/grl.50686

817 Wan, Y., E. Lin, W. Xiong, and L. Guo. 2011. Modeling the impact of climate change on soil organic carbon

818 stock in upland soils in the 21st century in China. Agric. Ecosyst. Environ. 141:23-31.

819 doi:10.1016/j.agee.2011.02.004

820 Weihermüller, L., A. Graf, M. Herbst, and H. Vereecken. 2013. Simple pedotransfer functions to initialize

821 reactive carbon pools of the RothC model. Eur. J. Soil Sci. 64:567-575. doi:10.1111/ejss.12036

822 Yagüe, M.R., and D. Quilez. 2010a. Direct and residual response of wheat to swine slurry application

823 method. Nutr. Cycl. Agroecosyst. 86:161-174. doi:10.1007/s10705-009-9280-9

824 Yagüe, M.R., and D. Quilez. 2010b. Cumulative and residual effects of swine slurry and mineral nitrogen in

825 irrigated maize. Agron. J. 102:1682-1691. doi:10.2134/agronj2010.0282

826 Zhao, G., H. Webber, H. Hoffmann, J. Wolf, S. Siebert, and F. Ewert. 2015. The implication of irrigation in

827 climate change impact assessment: A European-wide study. Glob. Change Biol. 21:4031-4048.

828 doi: $10.1111 / \mathrm{gcb} .13008$

829

830

831

832

833 
838 Table 1. Changes in soil organic $\mathrm{C}$ content during the period of 2010 to 2100 for different agricultural systems and under five different climate scenarios (baseline, CGCM2-A2, CGCM2-B2, ECHAM4-A2, 840 and ECHAM4-B2) in the 0- to 30-cm soil layer.

\begin{tabular}{llllll}
\hline Agricultural classes $\dagger$ & Baseline & CGCM2-A2 & CGCM2-B2 & ECHMA4-A2 & ECHMA4-B2 \\
\cline { 2 - 3 } & 21.4 & 16.7 & 17.6 & 17.1 & 16.7 \\
RC & 46.2 & 39.5 & 39.1 & 29.4 & 28.2 \\
IC & 20.5 & 16.3 & 17 & 16 & 16.1 \\
OR & -4 & -6.3 & -6.1 & -7.5 & -7.4 \\
OG & 5.3 & 3 & 3.3 & 4.7 & 5 \\
V & & & & &
\end{tabular}

$841 \dagger \mathrm{RC}$, rainfed crops; IC, irrigated crops; OR, orchard; OG, olive groves; V, vineyard.

842

843

844

845

846 


\section{$850 \quad$ Figures}

851

852

853

854

855

856

857

858

859

860

861

862

863

864

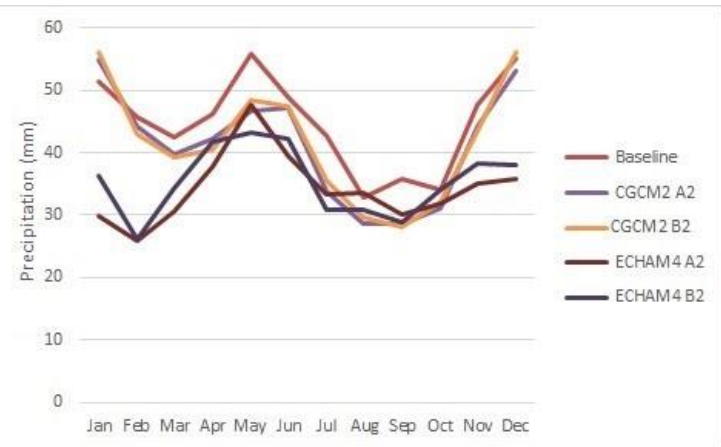

Fig. 1. Mean monthly air temperature and precipitation distribution for the different climate scenarios during the 2010-2100 period in the Aragon region.

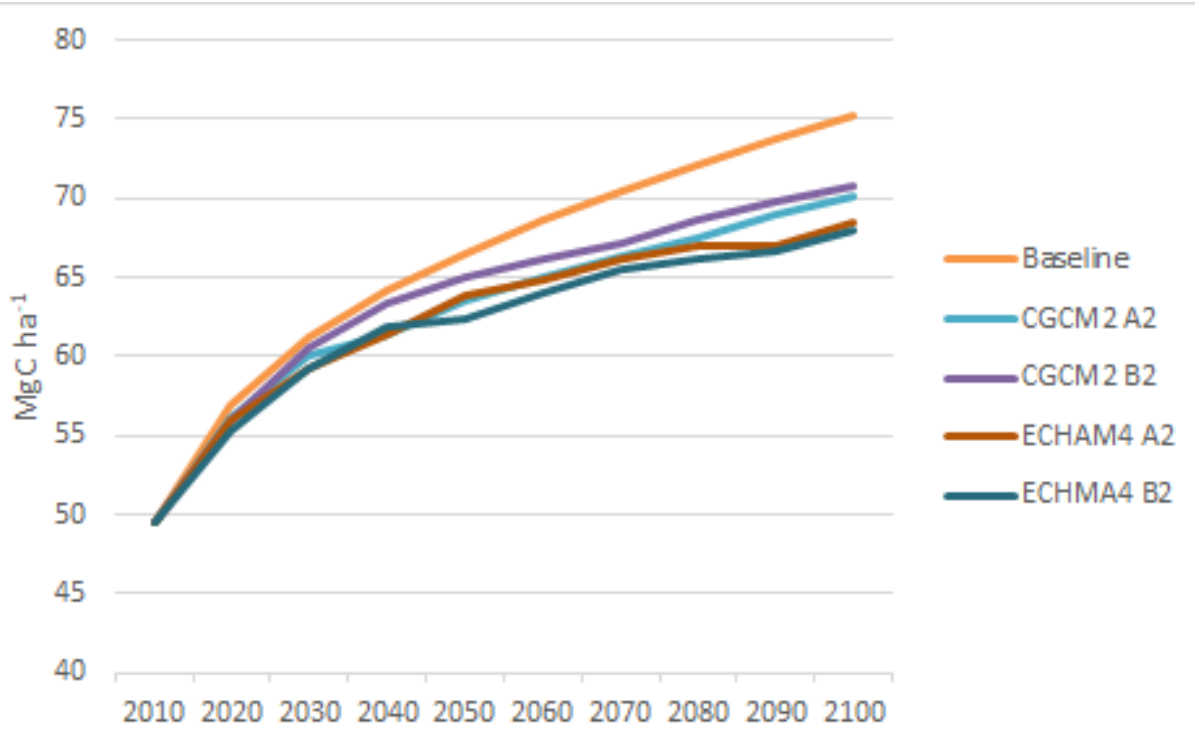

Fig. 2. Soil organic carbon (SOC) content evolution under the Baseline scenario and the four climate scenarios tested (CGCM2 A2, CGCM2 B2, ECHAM4 A2, ECHAM4 B2) during the 2010-2100 period at the $0-30 \mathrm{~cm}$ soil layer in the agricultural surface of the Aragon region. 

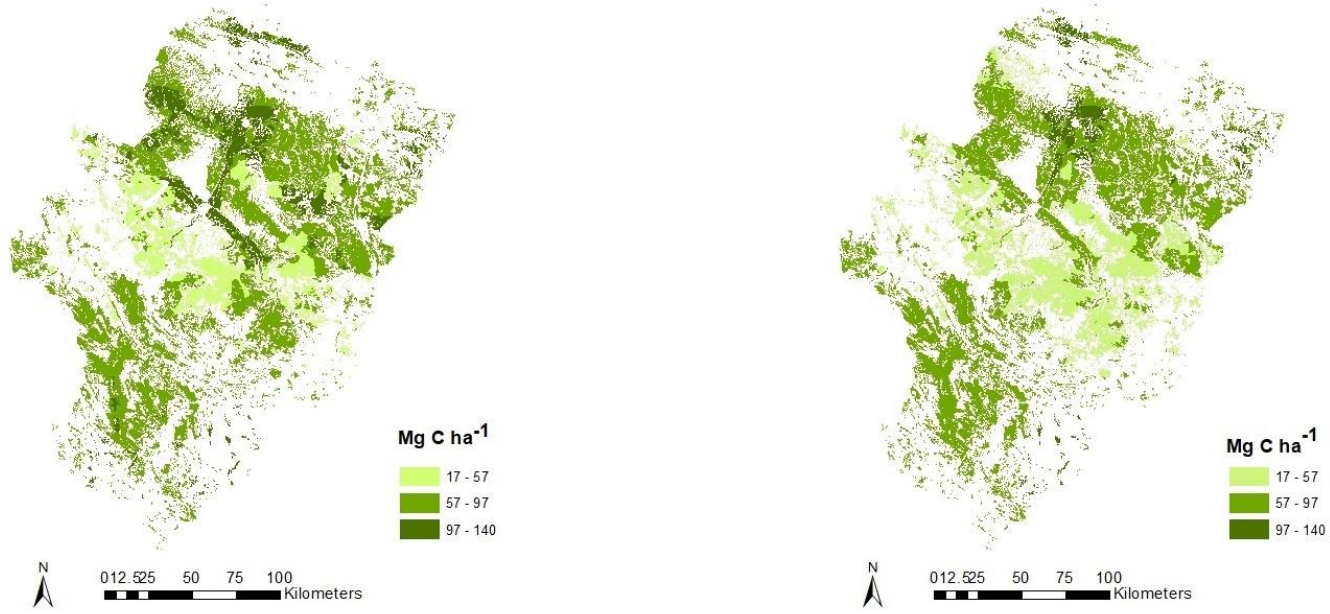

865

866 Fig. 3. Spatial distribution of soil organic (SOC) content in 2100 under the Baseline 867 scenario (on the left) and the ECHAM4-A2 climate change scenario (on the right) at the 0$86830 \mathrm{~cm}$ soil layer in the agricultural surface of the Aragon region.

869

870

871

872 
873

874

875

876

877

878

879

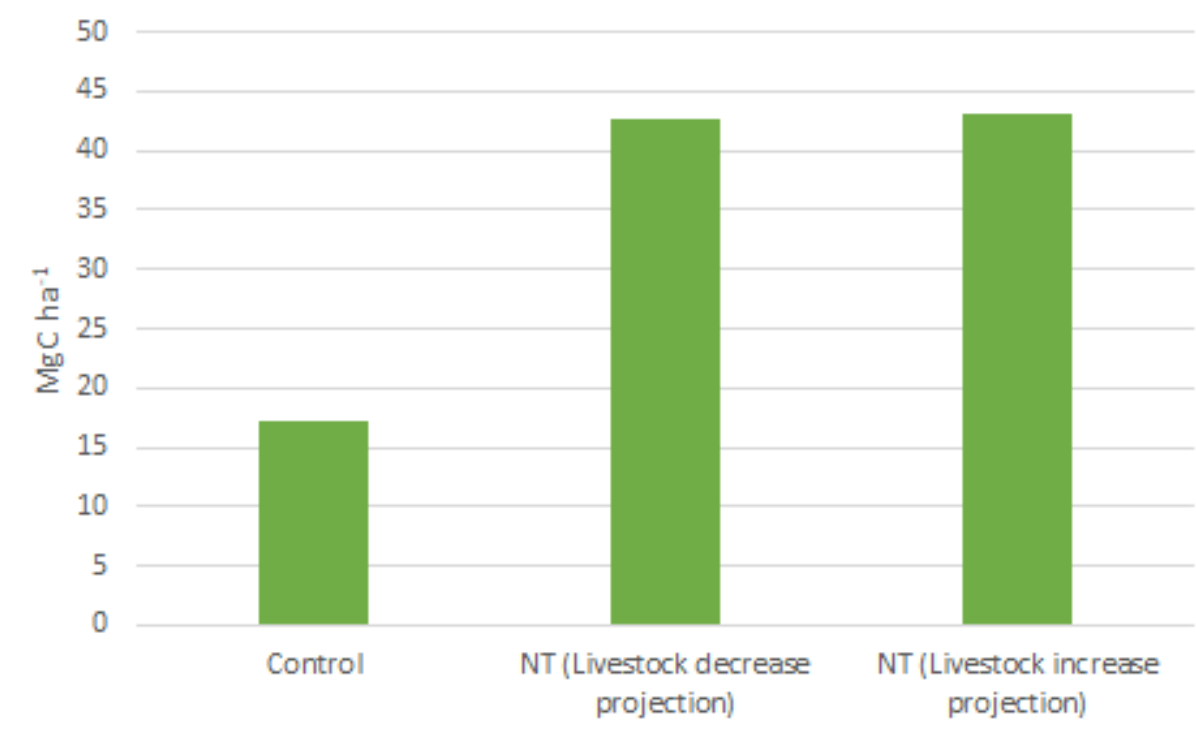

Fig. 4. Changes in soil organic carbon content for the $0-30 \mathrm{~cm}$ soil layer in the rain-fed crop (RC) system between the control scenario and the two no-tillage (NT) scenarios (livestock decrease and increase) under the ECHAM4 A2 climate change scenario during the 2010-2100 period.

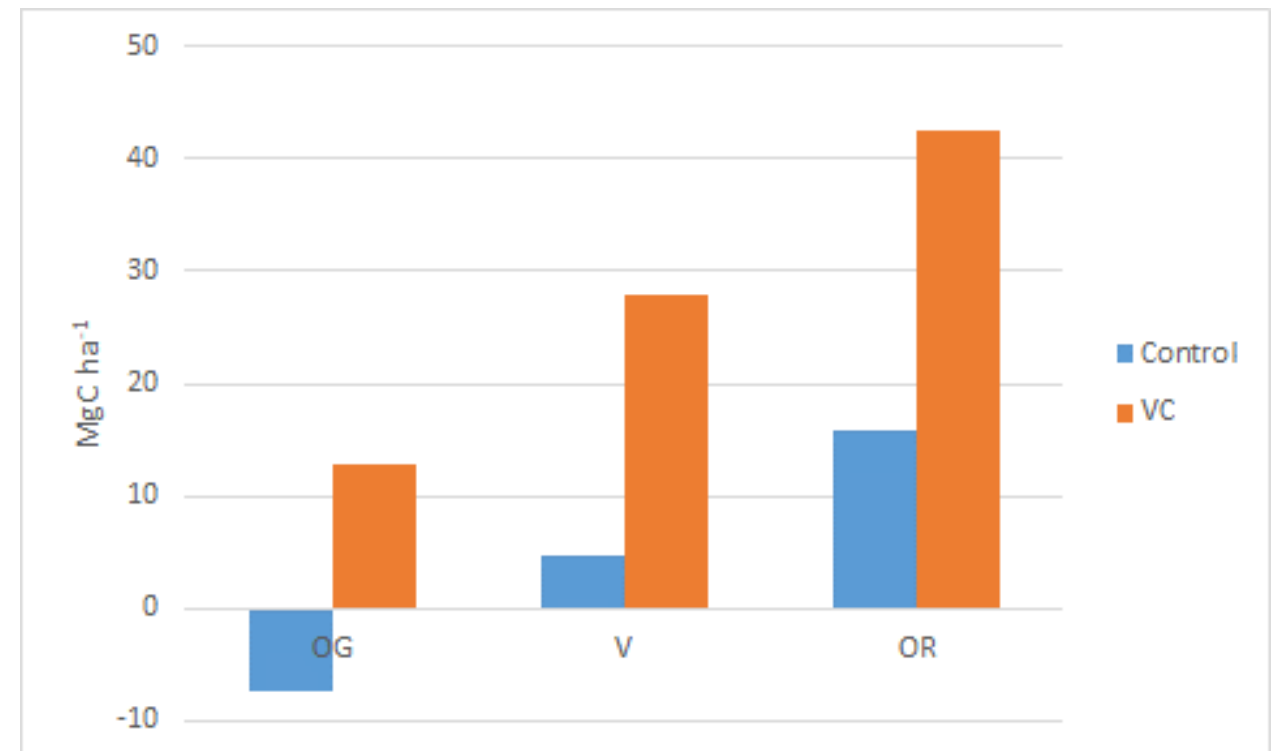

Fig.5. Changes in soil organic carbon (SOC) content for the $0-30 \mathrm{~cm}$ soil layer in the woody crop (WC) systems (orchards, OR; olive groves, OG; and vineyards, V) between the control scenario and the vegetation cover (VC) scenario under the ECHAM4 A2 climate change scenario during the 2010-2100 period. 